\title{
Diabetic Nephropathy; Clinical Characteristics and Treatment Approaches
}

\author{
Derun Taner Ertugrul, Emre Tutal \\ and Siren Sezer \\ Keciören Research Hospital, Department of Internal Medicine \\ Division of Endocrinology and Metabolism \\ Baskent University Hospital, Department of Internal Medicine \\ Division of Nephrology \\ Turkey
}

\section{Introduction}

Diabetes mellitus is a major public health problem and its' prevalance is contuniously rising especially in developed or developing countries. According to World Health Organization (WHO) data the prevalence of diabetes for all age-groups worldwide was estimated to be $2.8 \%$ in 2000 and $4.4 \%$ in 2030 . The total number of people with diabetes is projected to rise from 171 million in 2000 to 366 million in 2030 (1). Despite of improved treatment options for both diabetes mellitus and other associated risk factors, diabetic nephropathy is still a major problem causing increased morbidity and mortality as the increase in total number of diabetic patients finds a reflection in increased prevalence of diabetic patients in end stage renal disease (ESRD) population. There are some studies reporting decreased incidence of diabetic nephropaty in developed countries as a result of better glycemic control and agressive treatment of hypertension with new generation antihypertensives (2). However total number of diabetic nephropathy patients seems to be increasing as a result of increased numbers of diabetic patients and diabetes has become the primary cause of ESRD in the developed countries. Approximately $44 \%$ of new patients entering dialysis in the United States are diabetics. In the United States, approximately 20.8 million people, or $7.0 \%$ of the population, are estimated to have diabetes, with a growing incidence. Roughly one third of this population, 6.2 million, is estimated to be undiagnosed with type 2 diabetes $(3,4)$. Similar to these findings prevalence of diabetic nephropahty also increases in in developing countries For example, according to Turkish Society of Nephrology data prevalence of diabetic ESRD patients increased form $7 \%$ to $32.5 \%$ from 1991 to 2008 . A similar trend was also observed for hypertensive nephropathy which raised from $6.3 \%$ to $26.8 \%$ (5). This hypertensive population is important as according to some previous reports, only one third of essential hypertension patients has normal blood glucose metabolism at diagnosis (6). So it is possible that prevalence of pure diabetic or pure hypertensive nephropathy is lower than predicted but the combination of these two pathological condition is very high in otherwise healthy and ESRD populations. 


\section{Risk factors}

Multiple risk factors for development of diabetic nephropathy were defined. Most important of these seems to be the duration of diabetes mellitus. $20-30 \%$ of type I diabetics are supposed to have clinically significant renal involvement (microalbuminuria) after 20 years duration and 15-20\% develop ESRD after an additional 10 year $(7,8)$. These durations are not well defined for type 2 diabetics. $5-25 \%$ of these patients might have clinically significant renal failure or even ESRD (1\%) at time of diagnosis and approximately $20-30 \%$ reach ESRD at 20 years duration (9). The impact of age at time of diabetes diagnosis on development of renal failure is not clear. Among patients with type 2 diabetes, increasing age, along with increasing duration of diabetes was reported to be associated with increased risk for developing albuminuria (10). However some contradicting studies report that, patients who developed diabetes prior to age 20 had a higher risk of progressing to endstage renal disease (25 versus 5 per 1000 patient years at risk) (11). For type 1 diabetes, the risk of developing ESRD was reported to be very low for patients diagnosed prior to age 5; however at older ages, the relationship of age to progression to ESRD is uncertain $(12,13)$.

Poor glycemic control is another important risk factor for development of diabetic renal involvement. The Diabetes Control and Complications Trial (DCCT) demonstrated that interventions that improve glycemic control in patients with type 1 diabetes mellitus reduce the risk of development and slow the progression of diabetic microvascular disease, and may also protect against the occurrence of macrovascular disease (14). The United Kingdom Prospective Diabetes Study (UKPDS), a study of over 4000 patients with prolonged followup, suggests that strict control also results in a reduced risk of microvascular disease in patients with type 2 diabetes (15).

Hypertension, another important risk factor, is very common in diabetic patients. In fact hypertension is a cause and also a result of diabetic renal disease. Among those with type 1 diabetes, the incidence of hypertension rises from $5 \%$ at 10 years, to $33 \%$ at 20 years, and $70 \%$ at 40 years (16). The blood pressure typically begins to rise within the normal range about three years after the onset of microalbuminuria. Ultimately, the incidence of hypertension is approximately 15 to $25 \%$ in all patients with microalbuminuria and 75 to $85 \%$ in those with overt diabetic nephropathy (17). On the other hand type 2 diabetic patients have different characteristics. Most of them already have hypertension, even without renal involvement/microalbuminuria at the time of diagnosis (18). Also essential hypertension patients have some glucose metabolism abnormalities including insukin resistance without overt diabetes at time of diagnosis (6).

Obesity and hyperlipidemia might also cause progression of diabetic nephropathy while weight loss and control of hyperlipidemia by using statins might improve renal status (1922).

Approximately one-half of patients with type 1 diabetes of less than five years duration have an elevated glomerular filtration rate (GFR) that is 25 to 50 percent above normal and this situation was reported to have negative effects on disease progression (23). If GFR is above $150 \mathrm{~mL} / \mathrm{min}$ risk for developing microalbuminuria significantly increases. In one prospective study, for example, patients with type 1 diabetes and a GFR above $125 \mathrm{~mL} / \mathrm{min}$ had a risk of developing microalbuminuria within 8 years of approximately 50 percent versus only 5 percent in patients with a lower GFR that was similar to that seen in nondiabetics (23). 
Some genetic susceptibilities for developing diabetic renal disease were also reported. Most important of these factors are race, family tendencies and ACE gene polymorphisms (24-28). Considering gene polymorphisms; in patients with type 2 diabetes, the ACE/DD polymorphism was reported to associate with an increased risk for the development of diabetic nephropathy, more severe proteinuria, greater likelihood of progressive renal failure, and mortality on dialysis (26-28).

\section{Pathophysiology}

Development of diabetic nephropathy depends on different pathogenic processess. Major of these pathyways will be summarized below

a. Glomerular hyperfiltration: Studies in experimental animals indicate that dilatation of the afferent (precapillary) glomerular arteriole plays an important role in the hyperfiltration response, by raising both the intraglomerular pressure and renal blood flow (29). Some hormonal factors including insulin-like growth factor I (IGF-1), atrial natriuretic factor and sex hormones were speculated to have effects on hyperfiltration. Most important of these seems to be IGF-1 which induces hyperfiltration, renal vasodilatation and hypertropy in experimental models (30). Increased intracellular sorbitol accumulation, hyperglycemia, glycosylation endproducts and increased sodium reabsorption and tubuloglomerular feedback also has effects on glomerular hyperfiltration

b. Hyperglycemia and AGEs: Hyperglycemia is known to have a direct effect on mesangial expansion and injury, a result possibly secondary to increased matrix production or glycosylation of matrix proteins. Glycosylation of tissue proteins also may contribute to the development of diabetic nephropathy. Chronic hyperglycemia causes nonenzymatic glycosylation of free amino acids on circulating or tissue proteins and this process forms reversible early glycosylation products and later irreversible advanced glycosylation end products (AGEs). Circulating AGE levels are increased in particularly diabetics with renal insufficiency, because AGEs are normally excreted in the urine. The net effect is tissue accumulation of AGEs, in part by crosslinking with collagen, which can contribute to the associated renal and microvascular complications $(31,32)$.

c. Prorenin: A recent experimental model has reported a possible pathogenic role for prorenin in the development of diabetic nephropathy in which prolonged prorenin receptor blockade prevented the development of nephropathy without alterin angiotensin II activity (33).

d. Proinflammatory cytokines and growth factors: A group of proinflammatory, profibrotic cytokines and growth factors were speculated to have effects on diabetic nephropathy pathogenesis. Most important of these are vascular endothelial growth factor (VEGF), transforming growth factor - beta (TGF-ß). Experimental models reported that VEGF blockade improves albuminuria in diabetic nephropathy (34). Similarly the combination of an anti-TGF-beta antibody and an ACE inhibitor completely normalized proteinuria in experimental diabetic nephropathy models (35).

e. Proteinuria: Final result of above mentioned pathogenic factors is proteinuria. Normal protein discharge in urine is lower than $30 \mathrm{mg} /$ day for albumin and $150 \mathrm{mg} /$ day for total protein. Microalbuminuria $(30-300 \mathrm{mg} /$ day) is a critical treshold for diabetic nephropathy and after this stage untreated patients usually develop overt proteinuria 
(> $300 \mathrm{mg} /$ day microalbuminuria). Proteinuria was reported to induce inflammation, fibrosis, and it is also have direct tubular toxicity which all promote development of diabetic nephropathy

\section{Histopathological changes}

All components of renal infrastructure can be affected by diabetic nephropathy. Some of these changes are specific for diabetes, some not. Most common and important changes are capillary basal membrane thickening, diffuse glomerulosclerosis and nodular glomerulosclerosis (Kimmelstiel - Wilson nodules). Nodular glomerulosclerosis was described by Kimmelstiel and Wilson in 1936. These nodules are eosinophilic and PAS positive hard masses which are located in the central regions of peripheral glomerular lobules. They appear to be of mesengial origin and when they are pathogomonic for diabetic nephropathy however they are not universal and found only in $10-40 \%$ of patients. The diffuse mesengial lesions are more frequent than nodular glomerulosclerosis and present in $50-90 \%$ of patients. They include increased mesengial matrix, basala membrane thickening, capillary narrowing, hyalinization and periglomerular fibrosis. Afferent and efferent arteriolar hyalnization is highly specific for diabetic nephropathy, on the other hand only afferent arteriol involvement is a finding of hypertensive nephrosclerosis.

\section{Clinical manifestations and natural history}

Clinical stages of type 1 diabetes mellitus renal involvement is summarized in Table- 1 . These stages are also accepted for type 2 diabetic patients however they might not always follow these steps (36). ESRD is not the only major consequence of diabetic nephropathy but patients have increased risk of cardiovascular disease, morbidity and mortality even in the early stages of nephropathy. Microalbuminuria $(30-300 \mathrm{mg} /$ day albuminuria) is the first clinical sign of diabetic nephropathy and this situation is highly associated with other complications of diabetes like cardiovascular disease and retinopathy. 24 hour urine or spot urine albumin / creatinine ratios should be used for microalbuminuria follow-up. Overt proteinuria is defined as $>300 \mathrm{mg} /$ day albuminuria and at this stage total protei, $\mathrm{n}$ loss in urine might exceed $1 \mathrm{~g} /$ day. 5-7 years after development of overt proteinuria these patients usually develop ESRD.

\section{Diagnosis and differential diagnosis}

Proteinuria developing in a diabetic patient is an important marker for diabetic nephropathy however in case of atypical presentation renal biopsy might be indicated. A typical diabetic nephropathy presentation is a type 1 diabetes history for at least 10 years, presence of retinopathy, previous microalbuminuria, no macroscopic hematuria and microscopically inactive urinary sediment. Type 2 diabetic patients might not have this kind of a clinic and as previously mentioned $5-25 \%$ of these patients might have clinically significant renal failure or even ESRD (1\%) at time of diabetes diagnosis (9). In case of atypical presentation a renal biopsy is usually indicated. Possible atypical presentations are as follows; short diabetes duration (> 10 yrs for type 1 diabetics), no previous retinopathy, overt proteinuria without previous microalbuminuria, macroscoic hematuria, red cell or leucocyte casts, presence of systemic manifestations of any other disease that also can 
involve kidneys like collagen tissue disorders, amyloidosis etc, rapid decline in renal function without significant proteinuria. Long diabetes duration, previous retinopathy and microalbuminuria might not always be present in type 2 diabetics so in these patients presence of glomerulonephritis clinical features or any other systemic disease with possible renal involvement are biopsy indications.

\begin{tabular}{|c|c|c|c|c|c|c|}
\hline Stage & $\begin{array}{c}\text { Duration of } \\
\text { diabetes } \\
\text { mellitus }\end{array}$ & $\begin{array}{l}\text { GFR and } \\
\text { renal } \\
\text { perfusion }\end{array}$ & $\begin{array}{l}\text { Urine } \\
\text { findings }\end{array}$ & $\begin{array}{l}\text { Serum } \\
\text { findings }\end{array}$ & $\begin{array}{l}\text { Clinical } \\
\text { findings }\end{array}$ & $\begin{array}{l}\text { Morpho- } \\
\text { logical } \\
\text { findings }\end{array}$ \\
\hline $\begin{array}{l}\text { 1. Nephro- } \\
\text { megaly and } \\
\text { hyper- } \\
\text { filtration } \\
\text { stage }\end{array}$ & At diagnosis & Increased & $\begin{array}{c}\text { Reversible } \\
\text { albuminuria }\end{array}$ & $\begin{array}{l}\text { No } \\
\text { significant } \\
\text { finding }\end{array}$ & $\begin{array}{l}\text { Increased } \\
\text { renal size }\end{array}$ & $\begin{array}{c}\text { Glomerular } \\
\text { hypertrophy }\end{array}$ \\
\hline $\begin{array}{l}\text { 2. Latent } \\
\text { stage }\end{array}$ & 2-5 years & $\begin{array}{c}\text { Normal/Incr } \\
\text { eased }\end{array}$ & $\begin{array}{l}\text { No } \\
\text { significant } \\
\text { finding }\end{array}$ & $\begin{array}{l}\text { No } \\
\text { significant } \\
\text { finding }\end{array}$ & $\begin{array}{c}\text { No significant } \\
\text { finding }\end{array}$ & $\begin{array}{c}\text { Increased } \\
\text { basal } \\
\text { membrane } \\
\text { thickness }\end{array}$ \\
\hline $\begin{array}{l}\text { 3. Incident } \\
\text { diabetic } \\
\text { nephropathy } \\
\text { stage }\end{array}$ & $5-15$ years & $\begin{array}{c}\text { Normal/Incr } \\
\text { eased }\end{array}$ & $\begin{array}{c}\text { Microalbumi } \\
\text { nuria (30-300 } \\
\text { mg/day) }\end{array}$ & $\begin{array}{l}\text { No } \\
\text { significant } \\
\text { finding }\end{array}$ & Hypertension & $\begin{array}{c}\text { Increased } \\
\text { basal } \\
\text { membrane } \\
\text { thickness and } \\
\text { mesengial } \\
\text { expansion }\end{array}$ \\
\hline $\begin{array}{c}\text { 4. Overt } \\
\text { diabetic } \\
\text { nephropathy } \\
\text { stage }\end{array}$ & $10-25$ years & $\begin{array}{c}\text { Decreasing } \\
\text { progressively }\end{array}$ & $\begin{array}{c}\text { Overt } \\
\text { proteinuria }\end{array}$ & $\begin{array}{l}\text { Increased } \\
\text { creatinine }\end{array}$ & \begin{tabular}{|} 
Hypertension \\
and \\
significant \\
nephropathy
\end{tabular} & $\begin{array}{c}\text { Diffuse/nod } \\
\text { ular } \\
\text { glomeruloscl } \\
\text { erosis }\end{array}$ \\
\hline $\begin{array}{c}\text { 5. End stage } \\
\text { renal disease } \\
\text { stage }\end{array}$ & $15-30$ years & Decreased & $\begin{array}{c}\text { Overt } \\
\text { proteinuria }\end{array}$ & Uremia & $\begin{array}{c}\text { Hypertension } \\
\text { and } \\
\text { significant } \\
\text { nephropathy }\end{array}$ & $\begin{array}{c}\text { Glomeruloscl } \\
\text { erosis }\end{array}$ \\
\hline
\end{tabular}

\section{Table 1.}

Diabetic patients are also prone to some renal diseases or complications which might need to be differentialy diagnosed. Almost every form of glomerular diseases were reported in diabetic nephropathy patients however membranous nephropathy is the most common one. Papillary necrosis, renovascular diseases (arterial or venous), bladder autonomic neuropathy, acute or chronic pyelonephritis, radiocontrast nephropathy and renal tuberculosis should always be kept in mind while evaluating a diabetic patient with renal findings. 


\section{Treatment and prevention of diabetic nephropathy}

Strict glycemic control decreases development of diabetic nephropathy in both type 1 and 2 diabetics. Intensive insulin therapy partially reverse the glomerular hypertrophy and hyperfiltration, delay the development of microalbuminuria, reduce the onset or progression of diabetic nephropathy compared to less intensive therapy, stabilize or decrease protein excretion in patients with microalbuminuria $(14,15,37,38)$. Intensive glycemic not only slow or even prevent development of diabetic nephropathy but also decrease morbidit and mortality ferom other diabetic complications. However the less prominent benefit from strict glycemic control in overt diabetic nephropathy indicates that factors other than hyperglycemia contributes to the glomerular injury. Reducing the intraglomerular pressure with dietary protein restriction or antihypertensive therapy with an angiotensin converting enzyme (ACE) inhibitor or angiotensin receptor blocker (ARB) can minimize progression of or even prevent glomerular disease in the absence of glycemic control. There is now clear evidence that antihypertensive therapy (particularly with RAS blockers) and perhaps protein restriction can reduce the rate of progression in patients with type 1 diabetes and overt nephropathy.

Hypertension increases rate of diabetic nephropathy progression. DCCT and UKPDS trialsdemonstrated that strict blood pressure control decreases microalbuminburia and macroalbuminuria development by $29 \%$ and 39\% respectively in 6 years follow-up period $(14,15)$. WHO and JNC advises to keep blood pressure below $130 / 80 \mathrm{mmHg}$ in diabetic patients. In JNC-VII quideline even a lower level $(125 / 75 \mathrm{mmHg})$ was proposed for prevention and/or slowing diabetic nephropathy progression (39). ACEI preference in diabetic patients is also recommended in these quidelines. ACEI not only decrease intraglomerular pressure (so decrease proteinuria) by their hemodynamic effects but also decrease glomeruler size and fibrotik process. ACEI were also reported to increase negative charge of basal membrane and so decrease proteinuria. ARBs could also be used alone or in combination with ACEI for increasing nephroprotection $(40,41)$. Nondihydropyridine class calcium antagonists (NDHCB) are also recommended as a combination with RAS blockers. In BENEDICT trial it was demonstrated that ACEI-NDHCB combination might delay development of microalbuminuria in hypertensive diabetic patients without proteinuria (42). Salt intake should be restricted $(<70 \mathrm{mEq} /$ day) for a beter antirpoteinuric effect as salt seems to blunt effects of both RAS blockers and NDHCB $(43,44)$. Aldosterone antagonists were also reported to reduce proteinuria when used alone, and to have an additive effect on proteinuria when used in combination with an ACE inhibitor or an ARB in both type 1 and type 2 diabetes $(36,45)$. Further blood pressure reduction may partially explain the beneficial effect, although an anti-inflammatory mechanism has also been proposed (46). However hyperkalemia in combination treatment ACEI/ARB and aldosterone antagonists) is a significant problem especially in advanced diabetic nephropathy.

Low protein diet decreases hyperfiltration in early stages of diabetic nephropathy and also could slow down GFR loss. However very low protein diets $(<0.6 / \mathrm{g} / \mathrm{kg} /$ day $)$ could cause malnutrition which is an important mortality risk factor in ESRD population so 0.8 $\mathrm{g} / \mathrm{kg} /$ day protein diets and essential amino acid supplementations are usually recommended (47).

Hyperlipidemia should also be screened in diabetic patients and must be treated with statins or fibrats if needed. Diabetic patients without hypertension but under simvastatin treatment were reported to have a $25 \%$ decrease in microalbuminuria levels (48). 


\section{Renal replacement treatment in diabetic esrd patients}

Diabetic patients usually need renal replacement therapy (RRT) in earlier stages of renal failure. It was reported that nondiabetic patients start receiving RRT when GFR falls below $10 \mathrm{ml} / \mathrm{min}$ but on the other hand diabetics need RRT with higher GFR $(15-20 \mathrm{ml} / \mathrm{min})$ levels (49). These patients are prone to hypervolemia and lung edema due to accompanying cardiac problems and malnutrition due to proteinuria and dietary restrictions. Diabetic patients developing diuretic resistant edema might need ultrafiltration and start RRT even with higher GFR values.

Patient survival in diabetics on maintenance dialysis is lower than that seen in nondiabetics with end-stage renal failure due to chronic glomerular disease or hypertension (50). As noted in the 2005 USRDS database, only approximately 25 percent of patients with diabetes survived five years after initiation of dialysis and cardiovascular disease is the most common cause of death, accounting for more than one-half of cases (50).

Renal transplantation is a choice of RRT in diabetic ESRD patients however five year survival is clearly lower than other ESRD patients ranging from $75 \%$ to $83 \%$ (51). Despite of this poor outcome, transplantation still result in decreased extrarenal vascular diseaseand better quality of life compared with either hemodialysis or peritoneal dialysis (51).

Making choice of dialysis modality in diabetic patients is similar with nondiabetic patients. Comorbid conditions, home situation, independence and motivation of the patient, ability to tolerate volume shifts, patients' desire, status of the vasculature and/or abdomen should be evaluated for each patient. The relative effect of hemodialysis and CAPD on survival in diabetic patients is uncertain. Initial reports suggested that CAPD was associated with a better outcome (52). However data from the USRDS case-mix study suggest that mortality may actually be increased in diabetic patients receiving CAPD (53). A subsequent very large study attempted to assess the impact of multiple risk factors, including diabetes, on survival after initiation of either hemodialysis or peritoneal dialysis. Utilizing data from 398,940 patients who initiated dialysis between the years 1995 to 2000 (54). Mortality risk was significantly higher on hemodialysis than PD among younger diabetics with no comorbidity. By comparison, hemodialysis was associated with a lower mortality risk in older diabetics with either no comorbidity or a baseline comorbidity.

\section{References}

Wild S, Roglic G, Gren A et al. Global prevalence of diabetes. Diabetes Care 2004; 27: 1047-53

Wolf G. New insights into the pathophysiology of diabetic nephropathy: from haemodynamics to molecular pathology. Eur J Clin Invest 2004; 34: 785-96 http://www.usrds.org/adr.htm

American Diabetes Association: Total Prevalence of Diabetes and Pre-diabetes, 2007. Available at

http://www.diabetes.org/diabetes-statistics/prevalence.jsp http://www.tsn.org.tr

Garcia-Puig J, Ruilope LM, Lugue M et al Glucose metabolism in patients with essential hypertension. Am J Med 2006; 119: 318-26

Orchard TJ, Dorman JS, Maser RE, et al. Prevalence of complications in IDDM by sex and duration. Pittsburgh Epidemiology of Diabetes Complications Study II. Diabetes 1990; 39:1116. 
Krolewski M, Eggers PW, Warram JH. Magnitude of end-stage renal disease in IDDM: a 35 year follow-up study. Kidney Int 1996; 50:2041.

Adler AI, Stevens RJ, Manley SE, Bilous, RW. Development and progression of nephropathy in type 2 diabetes: The United Kingdom Prospective Diabetes Study (UKPDS 64). Kidney Int 2003; 63:225.

Tapp RJ, Shaw JE, Zimmet PZ, et al. Albuminuria is evident in the early stages of diabetes onset: results from the Australian Diabetes, Obesity, and Lifestyle Study (AusDiab). Am J Kidney Dis 2004; 44:792.

Pavkov Me, Bennett PH, Knowler WC, et al. Effect of youth-onset type 2 diabetes mellitus on incidence of end-stage renal disease and mortality in young and middle-aged Pima Indians. JAMA 2006; 296:421.

Finne P, Reunanen A, Stenman S, et al. Incidence of end-stage renal disease in patients with type 1 diabetes. JAMA 2005; 294:1782.

Svensson M, Nystrom L, Schon S, Dahlquist, G. Age at onset of childhood-onset type 1 diabetes and the development of end-stage renal disease: a nationwide populationbased study. Diabetes Care 2006; 29:538.

The Diabetes Control and Complications Trial Research Group. The effect of intensive treatment of diabetes on the development and progression of long-term complications in insulin-dependent diabetes mellitus. N Engl J Med 1993; 329:977.

Intensive blood-glucose control with sulphonylureas or insulin compared with conventional treatment and risk of complications in patients with type 2 diabetes (UKPDS 33). UK Prospective Diabetes Study (UKPDS) Group. Lancet 1998; 352:837.

Epstein M, Sowers JR. Diabetes mellitus and hypertension. Hypertension 1992; 19:403.

Mogensen CE, Hansen KW, Pedersen MM, Christensen, CK. Renal factors influencing blood pressure threshold and choice of treatment for hypertension in IDDM. Diabetes Care 1991; 14 Suppl 4:13.

Hypertension in Diabetes Study (HDS): I. Prevalence of hypertension in newly presenting type 2 diabetic patients and the association with risk factors for cardiovascular and diabetic complications. J Hypertens 1993; 11:309.

Gelber RP, Kurth T, Kausz AT, et al. Association between body mass index and CKD in apparently healthy men. Am J Kidney Dis 2005; 46:871.

Ejerblad E, Fored CM, Lindblad P, et al. Obesity and risk for chronic renal failure. J Am Soc Nephrol 2006; 17:1695.

Morales E, Valero MA, Leon M, et al. Beneficial effects of weight loss in overweight patients with chronic proteinuric nephropathies. Am J Kidney Dis 2003; 41:319.

Zoja C, Corna D, Gagliardini E et al. Adding a statin to a combination of ACE inhibitor and ARB normalizes proteinuria in experimental diabetes, which translates into full renoprotection. Am J Physiol Renal Physiol. 2010 Nov;299(5):F1203-11

Rudberg S, Persson B, Dahlquist G. Increased glomerular filtration rate as a predictor of diabetic nephropathy An 8-year prospective study. Kidney Int 1992; 41:822.

Pettitt DJ, Saad MF, Benneth PH et al. Familial predisposition to renal disease in two generations of Pima Indians with type 2 diabetes mellitus. Diabetologia 33: 438-43, 1990

Earle K, Walker J, Hill C et al. Familial clustering of cardiovascular disease in patients with insulin dependent diabetes and nephropathy. N Eng J Med 7: 2627-35, 1996 
Jeffers BW, Estacio RO, Raynolds MV et al. Angiotensin-converting enzyme gene polymorphism in non-insulin dependent diabetes mellitus and its relationship with diabetic nephropathy. Kidney Int 1997; 52:473.

Yoshida H, Kuriyama S, Atsumi Y, et al. Angiotensin I converting enzyme gene polymorphism in non-insulin-dependent diabetes mellitus. Kidney Int 1996; 50:657.

Kuramoto N, Lizuka T, Ito H, et al. Effect of ACE gene on diabetic nephropathy in NIDDM patients with insulin resistance. Am J Kidney Dis 1999; 33:276.

Bank N. Mechanisms of diabetic hyperfiltration. Kidney Int 1991; 40:792.

Hirschberg R, Kopple JD. The growth hormone-insulin-like growth factor I axis and renal glomerular filtration. J Am Soc Nephrol 1992; 2:1417.

Makita Z, Radoff S, Rayfield EJ, et al. Advanced glycosylation end products in patients with diabetic nephropathy. N Engl J Med 1991; 325:836.

Singh AK, Mo W, Dunea G at al. Effect of glycated proteins on the matrix of glomerular epithelial cells. J Am Soc Nephrol 1998; 9:802.

Ichihara A, Suzuki F, Nakagawa T, et al. Prorenin receptor blockade inhibits development of glomerulosclerosis in diabetic angiotensin II type 1a receptor-deficient mice. J Am Soc Nephrol 2006; 17:1950.

Sung SH, Ziyadeh FN, Wang A, et al. Blockade of vascular endothelial growth factor signaling ameliorates diabetic albuminuria in mice. J Am Soc Nephrol 2006; 17:3093.

Benigni A, Zoja C, Corna D et al. Add-on anti-TGF-beta antibody to ACE inhibitor arrests progressive diabetic nephropathy in the rat. J Am Soc Nephrol 2003; 14:1816.

Mogensen CE, Cooper ME. Diabetic renal disease: from recent studies to improved clinical practice. Diabet Med 2004; 21: 4-17

Shichiri M, Kishikawa H, Ohkubo Y et al. Long-term results of the Kumamoto Study on optimal diabetes control in type 2 diabetic patients. Diabetes Care 2000; 23 Suppl 2:B21.

Sustained effect of intensive treatment of type 1 diabetes mellitus on development and progression of diabetic nephropathy: the Epidemiology of Diabetes Interventions and Complications (EDIC) study. JAMA 2003; 290:2159.

Chobanian AV, Bakris GL, Black HR et al. National Heart, Lung and Blood Institute Joint National Committee on Prevention, Detection, Evaluation, and Treatment of High Blood Pressure; National High Blood Pressure Eduv-cation Program Coordinating Committee. Comment in: The Seventh Report of the Joint National Committee on Prevention, Detection, Evaluation and Treatment of Higgh Blood Pressure: JNC 7 report. JAMA 2003; 289: 2560-72

Lewis EJ, Hunsicker LJ, Clarke WR et al. Renoprotective effect of the angiotensin receptor antagonist irbesartan in patients with type 2 diabetes. N Eng J Med 2001; 345: 851-8

Brenner BM, Goper ME, de Zeeuw D et al. RENAAL AStudy Investigators. Effects of losartan on renal and cardiovascular outcomes in patients with type 2 diabetes and nephropathy. N Eng J Med 2001; 345: 861-9

Ruggenenti P, Fassi A, Ilieva AP et al. Preventing microalbuminuria in Type 2 Diabetes. N Eng J Med 2004; 351: 1941-51

Bakris GL, Smith A. Effects of sodium intake on albumin excretion in patients with diabetic nephropathy treated with long-acting calcium antagonists. Ann Intern Med 1996; 125:201. 
Bakris GL, Weir MR. Salt intake and reductions in arterial pressure and proteinuria. Is there a direct link?. Am J Hypertens 1996; 9:200S.

Rachmani R, Slavachevsky I, Amit, M, et al. The effect of spironolactone, cilazapril and their combination on albuminuria in patients with hypertension and diabetic nephropathy is independent of blood pressure reduction: a randomized controlled study. Diabet Med 2004; 21:471.

van den Meiracker AH, Baggen RG, Pauli, S, et al. Spironolactone in type 2 diabetic nephropathy: effects on proteinuria, blood pressure and renal function. J Hypertens 2006; 24:2285.

Han SY, Kim CH, Kim HS, et al. Spironolactone prevents diabetic nephropathy through an anti-inflammatory mechanism in type 2 diabetic rats. J Am Soc Nephrol 2006; 17:1362.

Tonolo G, Ciccares M, Brizi P et al. Reduction albumin excretion rate in normotensive microalbuminuric type 2 diabetic patients during long term simvastatin treatment. Diabetes Care 1997; 20: 1891-5

Stein G, Fünfstück R, Schiel R. Diabetes Mellitus and dialysis. Minerva Urol Nefrol 2004; 56 : 289-303

United States Renal Data System. Excerpts from the USRDS 2005 annual data report: Atlas of end-stage renal disease in the United States. Am J Kidney Dis 2006; 47(Suppl 1):S1.

Locatelli F, Pozzoni P, Del Vecchio L. Renal replacement therapy in patients with diabetes and end-stage renal disease. J Am Soc Nephrol 2004; 15 Suppl 1:S25.

Wolfe RA, Port FK, Hawthorne VM et al. A comparison of survival among dialytic therapies of choice: In-center hemodialysis versus continuous ambulatory peritoneal dialysis at home. Am J Kidney Dis 1990; 15:433.

Held PJ, Port FK, Turenne MN, et al. Continuous ambulatory peritoneal dialysis and hemodialysis: Comparison of patient mortality with adjustment for comorbid conditions. Kidney Int 1994; 45:1163.

Vonesh EF, Snyder JJ, Foley RN et al. The differential impact of risk factors on mortality in hemodialysis and peritoneal dialysis. Kidney Int 2004; 66:2389. 


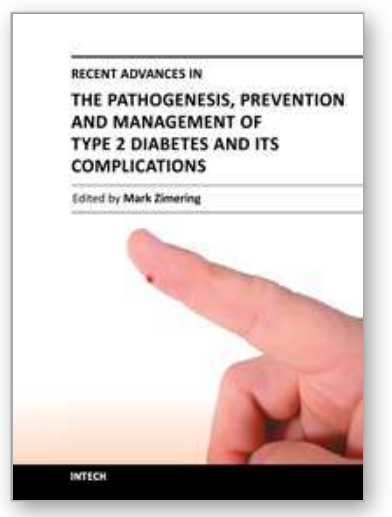

\author{
Recent Advances in the Pathogenesis, Prevention and \\ Management of Type 2 Diabetes and its Complications \\ Edited by Prof. Mark Zimering
}

ISBN 978-953-307-597-6

Hard cover, 442 pages

Publisher InTech

Published online 29, August, 2011

Published in print edition August, 2011

Type 2 diabetes â€œmellitusâ€ affects nearly 120 million persons worldwide- and according to the World Health Organization this number is expected to double by the year 2030. Owing to a rapidly increasing disease prevalence, the medical, social and economic burdens associated with the microvascular and macrovascular complications of type 2 diabetes are likely to increase dramatically in the coming decades. In this volume, leading contributors to the field review the pathogenesis, treatment and management of type 2 diabetes and its complications. They provide invaluable insight and share their discoveries about potentially important new techniques for the diagnosis, treatment and prevention of diabetic complications.

\title{
How to reference
}

In order to correctly reference this scholarly work, feel free to copy and paste the following:

Derun Taner Ertugrul, Emre Tutal and Siren Sezer (2011). Diabetic Nephropathy; Clinical Characteristics and Treatment Approaches, Recent Advances in the Pathogenesis, Prevention and Management of Type 2 Diabetes and its Complications, Prof. Mark Zimering (Ed.), ISBN: 978-953-307-597-6, InTech, Available from: http://www.intechopen.com/books/recent-advances-in-the-pathogenesis-prevention-and-management-of-type2-diabetes-and-its-complications/diabetic-nephropathy-clinical-characteristics-and-treatment-approaches

\section{INTECH}

open science | open minds

\section{InTech Europe}

University Campus STeP Ri

Slavka Krautzeka 83/A

51000 Rijeka, Croatia

Phone: +385 (51) 770447

Fax: +385 (51) 686166

www.intechopen.com

\section{InTech China}

Unit 405, Office Block, Hotel Equatorial Shanghai

No.65, Yan An Road (West), Shanghai, 200040, China

中国上海市延安西路65号上海国际贵都大饭店办公楼 405 单元

Phone: $+86-21-62489820$

Fax: +86-21-62489821 
(C) 2011 The Author(s). Licensee IntechOpen. This chapter is distributed under the terms of the Creative Commons Attribution-NonCommercialShareAlike-3.0 License, which permits use, distribution and reproduction for non-commercial purposes, provided the original is properly cited and derivative works building on this content are distributed under the same license. 